\title{
Behavioural adaptations of argulid parasites (Crustacea: Branchiura) to major challenges in their life cycle
}

\author{
V.N. Mikheev ${ }^{1 *}$, A.F. Pasternak ${ }^{2}$ and E.T. Valtonen ${ }^{3}$
}

\begin{abstract}
Fish lice (Argulus spp.) are obligate ectoparasites, which contrary to most aquatic parasites, retain the ability to swim freely throughout the whole of their life. In fish farms, they can quickly increase in numbers and without effective control cause argulosis, which results in the reduced growth and survival of their fish hosts. The morphology of Argulus spp, including their sensory organs, is suitable for both parasitism and free-swimming. By spending a considerable amount of time away from their host, these parasites risk being excessively dispersed, which could endanger mating success. Here we present a review of recent studies on the behaviour of Argulus spp, especially the aggregative behaviour that mitigates the dilution of the parasite population. Aggregation of parasites, which is especially important during the period of reproduction, occurs on different scales and involves both the aggregation of the host and the aggregation of the parasites on the host. The main behavioural adaptations of Argulus spp, including searches for hosts and mates, host manipulation and host choice, are all focused on the fish. As these ectoparasites repeatedly change hosts and inflict skin damage, they can act as vectors for fish pathogens. The development of environmentally friendly measures for the control and prevention of argulosis needs to take into account the behaviour of the parasites.
\end{abstract}

Keywords: Fish ectoparasites, Argulus foliaceus, Argulus coregoni, Aggregative behaviour, Host searching, Behavioural tactics, Vectors

\section{Introduction}

Although the behaviour of parasites has attracted serious attention [1-4], it is still little studied when compared with their morphology and physiology. The high abundance of descendants and the efficient exploitation of hosts are widely accepted as the main determinants of parasite fitness [5, 6]. Despite the close association with their host, all macroparasites have dispersal stages, which help to expand the parasite's range, find hosts and facilitate genetic exchange. Heteroxenous parasites have to change hosts several times in their life history, whereas monoxenous forms are able to complete their life cycle on one host, as in the case of most parasitic copepods. Under such a strategy, the role of a free-

\footnotetext{
* Correspondence: vicnikmik@gmail.com

'Institute of Ecology and Evolution, Russian Academy of Sciences, 33

Leninskii pr, 119071 Moscow, Russia

Full list of author information is available at the end of the article
}

swimming stage is important only for the short period of dispersal.

However, there is a group of obligate aquatic ectoparasites of the subclass Branchiura, which also retain the ability to swim freely at the adult stage. The most diverse, abundant and widely distributed group of the Branchiura are species of the genus Argulus (fish lice), which parasitize fishes $[7,8]$. Species of this genus inhabit mainly freshwaters from the Tropics to the Holarctic. The behavioural complex of argulids, from larvae to mature adults, includes behaviour on the host and behaviour when free-swimming. We will focus on the behaviour of Argulus spp. when free-swimming and, later on, address the term 'behaviour' to this part of the behavioural complex.

Swimming Argulus spp. are easily dispersed, both by water currents and their own activity. Parasite dispersal associated with water movements has received much attention in studies on sea lice [9]. Dispersal may decrease 
the local density of parasites and hamper mate finding. In boreal waters, where the density of fish and parasite populations is often low, this could seriously reduce the reproduction success of the parasite population. To increase encounters between parasites and their fish hosts and between parasite males and females, the dispersal of the fish lice should be counterbalanced by behaviour leading to their aggregation. The necessity to form aggregations makes the behaviour, especially movement and orientation, a pivotal aspect of the biology of Argulus spp. Such an aggregation could occur on the fish hosts, on various interfaces or via an attraction to each other in the water column.

Successful host searching tactics of free-swimming Argulus spp. needs to include adjustments to changing behaviour of their target fish. Are these parasites choosy or non-selective in relation to different fish species? Do they change their tactics according to diurnal changes in fish behaviour? Can monoxenous argulids manipulate their fish hosts as some trophically transmitted heteroxenous parasites do [10-12]? When parasites have matured and are ready to reproduce the main challenge is to find a mate. Aggregation of both parasites and hosts would significantly facilitate a search for a mate. Are males and females different in their mate searching behaviour? What behaviours lead to an aggregated distribution of fish lice?

Despite our basic knowledge of simple behavioural responses and the main sensory modalities employed by free-swimming fish lice [13-15] and a recent book on biology and behaviour of ectoparasites [16], we are still far from understanding the adaptations that enable fish lice to find both hosts and mates and maintain sustainable populations. A programme of experimental and field studies on the behaviour of Argulus foliaceus and $A$. coregoni has been carried out in Central Finland from 1997 onwards [17-23]. These two species are widely distributed in Eurasia and cause epizootics at fish farms [24]. Even more important could be knowledge of the role of argulids in the transmission of pathogens, such as bacteria, viruses and fungi, between fish.

The present paper aims to review recent findings on key aspects of fish lice behaviour when freeswimming, including the coordinated use of various sensory organs, and parasite movement and selective responses in relation to the hosts and conspecifics. We expect that knowledge of these aspects will help us understand how argulids meet the major challenges faced during their life history, to create measures against epizootics and to draw attention to their role as vectors of fish pathogens.

\section{Review}

Main sensory modalities and host searching tactics of fish lice

The first experimental study focusing on responses of $A$. foliaceus to environmental and host-induced stimuli was carried out by Konrad Herter [13], who concluded that this parasite encountered fish randomly. Surprisingly, $A$. foliaceus rarely reacted to the fish swimming as close as 3-5 cm from the parasite. Only closer contact ended with an attachment. It was shown that $A$. foliaceus, when close to the fish, responded primarily to water movements, chemical and tactile stimuli [13-15]. Vision was regarded as unimportant for host searching and served merely to discriminate between light and dark parts of the experimental tank [13].

A random encounter of hosts as the main mechanism for host finding is doubtful because the movement of small animals in a viscous medium is costly and extremely ineffective [25]. As to the role of vision, the large, well-developed, faceted eyes of A. foliaceus [26] suggest that vision is used for more than just for discriminating between light and dark. We repeated experiments on the host searching behaviour of A. foliaceus in glass aquaria similar to those used by Herter, and obtained virtually the same results [17]. Then, the experiment was repeated in aquaria with dark, non-reflective walls, which did not produce spurious visual targets. This simple change in experimental conditions resulted in a dramatic change in the swimming pattern and host searching efficiency of $A$. foliaceus [17]. Their swimming speed decreased by a factor of $4-5$, but the rate of attachment increased by almost a factor of 10 . We observed directional movements of $10-15 \mathrm{~cm}$ towards highly reflective objects and the attraction of $A$. foliaceus to most reflective fish $[17,18]$. In glass aquaria, the parasites appeared confused by numerous light spots, which impaired the use of vision.

The behaviour of A. foliaceus was different in the dark and light: two alternative host searching tactics were found (Table 1). In daylight, the parasite employed "hover-and-wait" tactics with low swimming speed and an inclined position of the body. In the dark, "cruising" tactics were employed, characterized by a much higher swimming speed and a horizontal position of the body [18]. Vision, olfaction and mechanoreception are used in daylight, whereas only the latter two are used at night (Table 1). Swimming speed was 5-6 times greater at night than in the daylight. Within both dark and light periods, swimming was controlled by both the hostinduced (visual, chemical and hydromechanical) and internal (state of hunger) factors. Host-induced cues increased mean swimming speed by a factor of $1.5-3$ [18]. In $A$. foliaceus starved for 1-2 days, the swimming speed was 3-4 times greater than that of fish 
Table 1 Fish lice are efficient host searchers, both day and night

\begin{tabular}{lll}
\hline Behavioural traits & Period & Night \\
\cline { 2 - 3 } Sensory modalities & Day & Olfaction Mechanoreception \\
Motor activity & Vision Olfaction Mechanoreception & High \\
Internal modifiers of activity & Low & Hunger state \\
Fish induced stimuli & Hunger state & Chemical Mechanical \\
Host searching tactics & Visual Chemical Mechanical & Cruising \\
More efficient at host searching & Hover-and-wait & Argulus foliaceus
\end{tabular}

Most quantitative estimations were obtained for Argulus foliaceus [17, 18]. Experimental data on olfaction, vision and host searching for A. coregoni [19, 20] are included

lice freshly detached from the host. A longer starvation caused a decrease in swimming activity [18].

With regard to changes in the use of the sensory organs during the ontogeny of fish lice, newly hatched larvae and early juveniles of $A$. coregoni were attracted by and reacted indiscriminately to every bright object. Among the test fishes they chose those species with highest reflectivity of the body (i.e. cyprinids, with silvery sides, compared to darker salmonids) [19]. The relative roles of vision and olfaction in host recognition changed with the maturation of parasites. From the age of about 3 weeks, $A$. coregoni did not respond to bright objects in the absence of a concomitant chemical stimulation, such as salmonid fish odour [19]. At this stage, A. coregoni had developed a strong preference for salmonid fishes [20]. The innate and ecological aspects of such preference will be discussed below.

\section{Argulus-fish behavioural interactions. Can fish lice manipulate their hosts?}

The host searching success of argulids depends not only on their behaviour and sensory abilities but also on host availability. We found that diurnal changes in the swimming patterns of juvenile perch (Perca fluviatilis) and roach (Rutilus rutilus) influenced the attachment rate of A. foliaceus. At night, perch move slowly and intermittently, which facilitates host searching for the parasite. Faster and continuously swimming roach were a less available target [17]. In the daytime, when both fishes moved continuously, the more reflective roach attracted significantly more parasites than perch [17]. The behaviour of $A$. foliaceus is well adjusted to the diurnal variation in the behaviour of the host: in the daytime, hover-and-wait tactics are used to intercept and attach to a nearby swimming fish; at night, cruising tactics are used to find and attach to slowly moving or stationary fish [18]. Increased nocturnal activity resulted in an increase in energy expenditure by more than $25 \%$ [18]. Free-swimming fish lice can survive outside the host for no longer than several days [14, 27]. At a low mean host density, these parasites would benefit if the fish were aggregated. Can Argulus spp. manipulate their host's behaviour to make them more available?

Two types of parasite-induced change in fish behaviour can be considered as host manipulation. A shortterm effect (seconds to tens of seconds) is related to behavioural responses of an individual fish (jerking, vigorous turning) to the attachment of $A$. canadensis [28] and A. foliaceus [29]. Such behaviour enhances visual, olfactory and mechanical stimulation, attracting more parasites to the already infected fish [30]. This results in an aggregated distribution of parasites among their hosts [28]. A similar aggregating mechanism has been observed in another ectoparasite-host system, i.e. copepods on brook trout fry [31]. Another type includes longer term effects (minutes to tens of minutes). The attachment of $A$. foliaceus to juvenile rainbow trout (Oncorhynchus mykiss) made them swim closer to each other, reducing swimming speed and aggression [29]. The consolidation of fish shoals and slower movement facilitates the transmission of parasites. We suggest that changes in fish behaviour are triggered by the release of an alarm substance from fish skin damaged by attached parasites. The formation of tight shoals is similar to the defence 
behaviour which fish exhibit when a conspecific fish is injured by a predator [32, 33]. We suggest that, in order to manipulate their hosts, parasites exploit this mechanism, which evolved in fish as an antipredatory behaviour [29].

Could other organisms influence behaviour of fish and Argulus spp. in a manipulatory way? If a pathogen uses Argulus spp. as vectors within the fish-Argulus system, it can influence characteristics of both the fish and the parasite, facilitating its own transmission. Fish infected with Flavobacterium columnare may develop columnaris disease with the symptoms of erosion and necrosis of the gills and skin, usually around the dorsal fin [34]. These injuries likely cause changes in any olfactory cues produced and in fish activity. Weakened fish reduce their swimming behaviour, which facilitates the attachment of A. foliaceus [18]. Bacteria may also impact on the behaviour of the hosts and vectors [35]. Olfactory cues signalling the presence of a debilitated fish might help the parasite in finding such a fish. Debilitated fish infected with Saprolegnia spp. carried much greater numbers of argulids compared with fish without a fungal infection (our unpublished data). This suggests that the host microbiota may affect attractiveness of hosts to vectors [36].

Vector competence is the ability of a vector to transmit a pathogen, i.e. "the intrinsic permissiveness of a vector to be infected, to replicate and to transmit a pathogen" [37]. Could a pathogen influence the frequency of host change by Argulus spp. to facilitate the transmission of a pathogen? Such a manipulation would be expected to focus on Argulus spp. males, because they are the most mobile members of the population. It has been said that many micro-organisms could be more powerful modifiers of their host's biology and behaviour than macroparasites [35, 38]. Adaptive modifications of behaviour of both Argulus spp and fish in a hostparasite-pathogen system require further studies.

\section{Host specificity. Why Argulus coregoni is more choosy than $A$. foliaceus?}

Argulus coregoni and the smaller A. foliaceus co-exist in the lakes and rivers of Central Finland. The distribution of these parasites among fish species is different. A. foliaceus is opportunistic and can be found on any fish species, with the highest abundance on perch, roach and pike [21,39], whereas $A$. coregoni is a specialist on salmonids [40, 41]. However, no host specificity was found during the early ontogeny of $A$. coregoni $[19,20]$. Metanauplii and early juveniles attach to every available fish, preferring the most reflective targets [19]. Host specificity developed with maturation, beginning at the preadult stage [20]. Increasing preference for salmonids was accompanied by an enhanced rate of detachments of fish lice, especially males, from the hosts $[42,43]$. By the spawning period, most $A$. coregoni had shifted to salmonids [20].

Why do these co-existing argulid species differ in their host preference? A. coregoni adults are much larger than those of A. foliaceus. Body length in mature A. coregoni

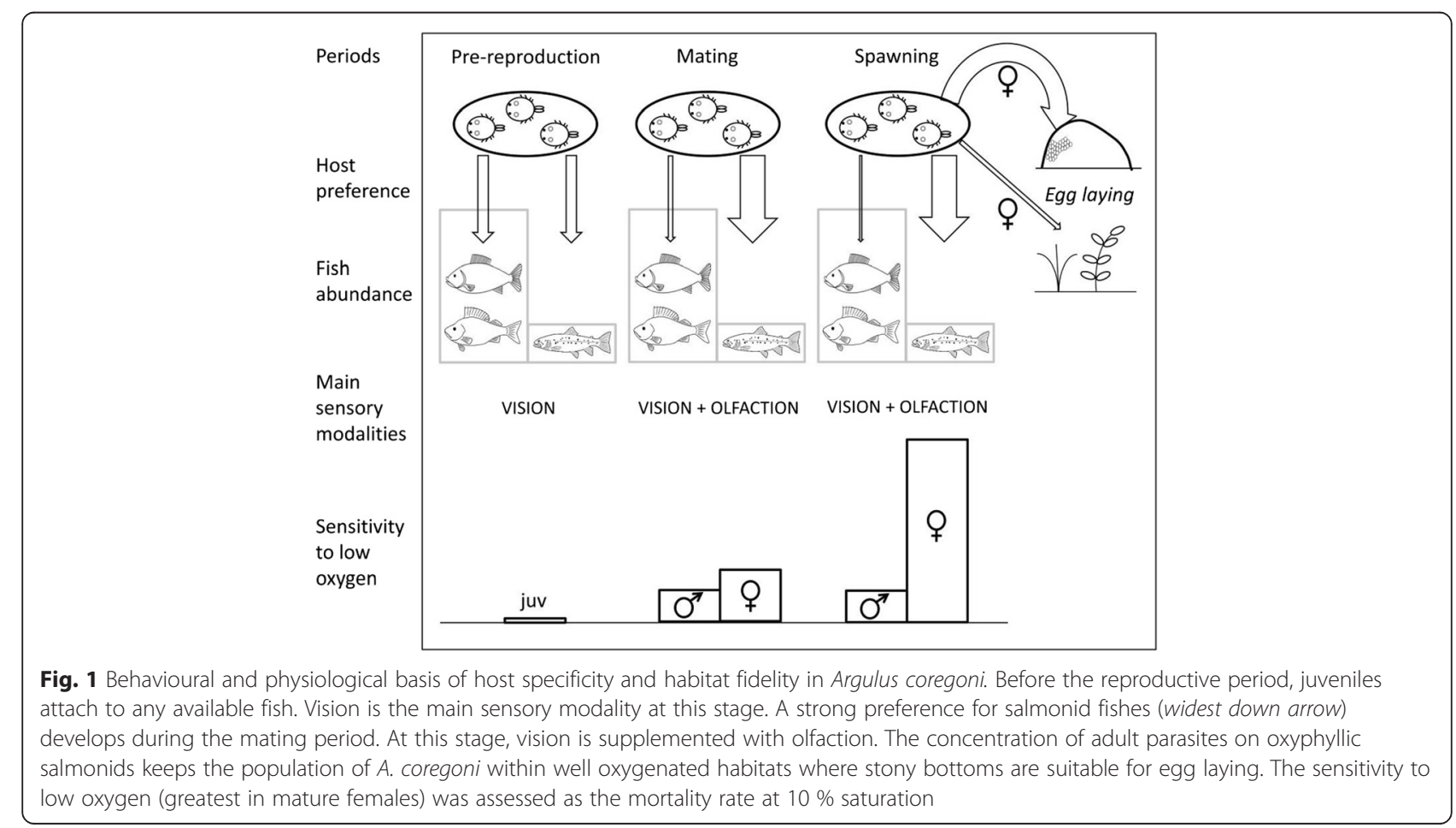


females is $13-15 \mathrm{~mm}$ [40], whereas that of A. foliaceus is about 5-7 $\mathrm{mm}$ [15]. The large size of $A$. coregoni is beneficial in terms of finding and attaching to large, agile salmonid fishes. On the other hand, the ratio of surface area to body volume in $A$. coregoni is about half that of A. foliaceus, which makes the former more sensitive to low oxygen concentration [20]. Gravid females are especially vulnerable to oxygen deficiency (Fig. 1) [20]. We consider that an increasing preference for salmonids in maturing $A$. coregoni helps them to remain in well oxygenated habitats.

The preference of $A$. coregoni for salmonids is innate and not acquired through habituation to the hosts to which the newly hatched larvae attach [20]. A. coregoni, reared on both cyprinids and salmonids, first exhibited a pronounced preference for salmonids when they reached the length of 4-5 $\mathrm{mm}$ [20]. However, this species retained the ability to develop, mature and spawn when only cyprinid hosts were available [22]. The ability of argulids to change hosts mitigates the difficult task of finding an appropriate host and habitat. Although the fitness of $A$. coregoni on non-salmonid hosts is lower than on salmonids (due to the more frequent detachments from non-salmonids and thus the shorter period of residence on them), these hosts could maintain the parasite population in cases of a sudden drop in the salmonid population.

Comparison between the two Argulus species emphasizes the role of body size as an important determinant of host searching behaviour, specificity and habitat preference in these parasites. The role of body size as a determinant of crucial physiological processes and their ecological effects is well known [25]. For closely related obligate parasite species of different sizes, size-based difference in behaviour and ecology was shown for the first time $[19,20]$. Large size is beneficial for host searching and attachment in running and turbulent waters, but it also imposes physiological and ecological limitations, restricting the distribution of $A$. coregoni within a water system. The difference in the preferred habitats of the two co-existing argulids is reflected in the relative importance of sensory organs. Vision is more important for A. coregoni, because olfaction and mechanoreception are of limited efficiency in their preferable habitats. The highest infection rate was recorded for $A$. coregoni during daylight, whereas, for $A$. foliaceus, it was during the dark [20]. On the other hand, A. foliaceus, which mostly inhabits still and turbid shallow waters, relies more on olfaction and mechanoreception.

\section{Reproduction and behaviour. Division of labour between males and females}

The aggregation of fish lice on fishes is a prerequisite for their successful mating [29], because even mature parasites fail to react to each other when swimming in water. Parasites on a heavily infected fish have no problems finding a conspecific specimen of the appropriate sex and state of maturity. If there are no appropriate mates on a host, the parasites must leave this host. Males of the two species play a leading role in mate searching. They frequently detach from the hosts (Table 2) and spend much more time swimming than females [21, 43]. Males of $A$. coregoni are able to detect and respond to sex pheromones produced by females attached to a fish [44]. We have observed that mature females of $A$. foliaceus swimming in the water do not attract males. Even at high concentrations (10 ind $\mathrm{l}^{-1}$ ), adult males do not react to females in water. Thus, the host provides Argulus spp. not only with food and substrate but also acts as a meeting point, provides transportation and triggers the stimuli that facilitate sexual interactions.

Males of fish lice risk energy loss and increased mortality while swimming and switching hosts. Females of both $A$. foliaceus and $A$. coregoni are stationary on their host [21, 44] and produce pheromones [44] like preadult female sea lice, Lepeophtheirus salmonis do when attracting males [45]. Together with the fish and their 'odour', females make large, attractive targets for males. Behavioural dimorphism between males and females is related to size dimorphism (Table 2). As in other ectoparasitic crustaceans, e.g. copepods, adult females of A. foliaceus and $A$. coregoni are markedly larger than adult males [21, 42]. However, at earlier life history stages, juvenile males of $A$. coregoni are the larger. They grow faster and are more numerous than females, until they reach the pre-reproductive period. Subsequently, males become smaller and less numerous than females (Table 2) [42]. This is due to food deprivation, high energy expenditure and an elevated risk of mortality of males while searching for mates.

Table 2 Reproduction, behaviour, sexual dimorphism and sex ratio of Argulus coregoni and A. foliaceus

\begin{tabular}{|c|c|c|c|c|}
\hline \multirow{2}{*}{$\begin{array}{l}\text { Period of } \\
\text { the life } \\
\text { cycle }\end{array}$} & \multicolumn{2}{|l|}{ Behaviour } & \multirow[t]{2}{*}{ Body size } & \multirow[t]{2}{*}{ Sex ratio } \\
\hline & Males & Females & & \\
\hline Juveniles & Strongly attached to host & Strongly attached to host & Males larger & Males more abundant \\
\hline Pre-adults & Moderate rate of detachment & Almost no detachments & Similar size & Similar abundance \\
\hline Adults & High rate of detachment - for mate searching & Low rate of detachment - for egg-laying & Females larger & Females more abundant \\
\hline
\end{tabular}

Data on body size and sex ratio of juveniles were obtained only for $A$. coregoni 
Females feed continuously, grow faster and accumulate energy for egg production.

In $A$. foliaceus and $A$. coregoni, both sexes bear the high energy costs of reproduction. Males spend a great amount of energy searching for a mate, whereas females invest heavily in egg production. Energy is also needed to search for an appropriate substrate for spawning. In general, the role of the sexes resembles that of parasitic copepods, but fish lice females, unlike copepod females [46], retain the ability to leave their hosts and swim freely even after laying a portion of their eggs. Females of Argulus spp. invest precious energy in a costly spawning behaviour, providing egg clutches with the suitable conditions for incubation. In choosing the appropriate sites for egg deposition females play an important role in maintaining the population within a favourable habitat.

\section{Behaviour, habitat fidelity and the life cycle of fish lice}

Behaviour, as mentioned above, plays a crucial role throughout the life of argulids between hatching and spawning. Besides searching for hosts and mates, behaviour is also essential in maintaining population integrity. For this purpose, parasites have to remain within restricted parts of a water body. This is particularly important at the beginning of the seasonal cycle, which starts with a mass hatching of metanauplii from the overwintered eggs. Newly hatched metanauplii must quickly find a host, so they need to be in areas of high fish abundance; these are the spawning and nursery grounds. This is guaranteed by gravid females laying their eggs either on stones (in the case of $A$. coregoni) or on vegetation in shallow littoral areas (for A. foliaceus). It was suggested that the location of egg laying is determined by the habitat usage of host fish [47].

Habitat fidelity and potential for aggregation in fish lice are associated not only with preferred egg laying areas of a particular species but also with ecologically distinct sets of fish hosts. A. foliaceus can be found on every fish species in lakes and rivers. They usually prefer fish inhabiting shallow stagnant waters, such as percids, cyprinids and esocids [39], A. foliaceus lays eggs on vegetation, wood debris and roots $[14,15]$. This relatively small species readily tolerates low oxygen concentrations [20] that often occur in shallow waters. The larger A. coregoni, especially at the adult stage, strongly prefers salmonid fishes inhabiting well oxygenated running waters. Such habitats are often associated with stony bottoms, the best substrate for A. coregoni egg laying [48]. Females choose dark-coloured stones of medium size, preferring sites that are not exposed to strong currents. Eggs are laid not too close to the bottom, so that sediments do not cover them $[23,48]$.

The life cycle of $A$. coregoni includes more interactions and links than previously believed e.g., [14, 49] (Fig. 2).

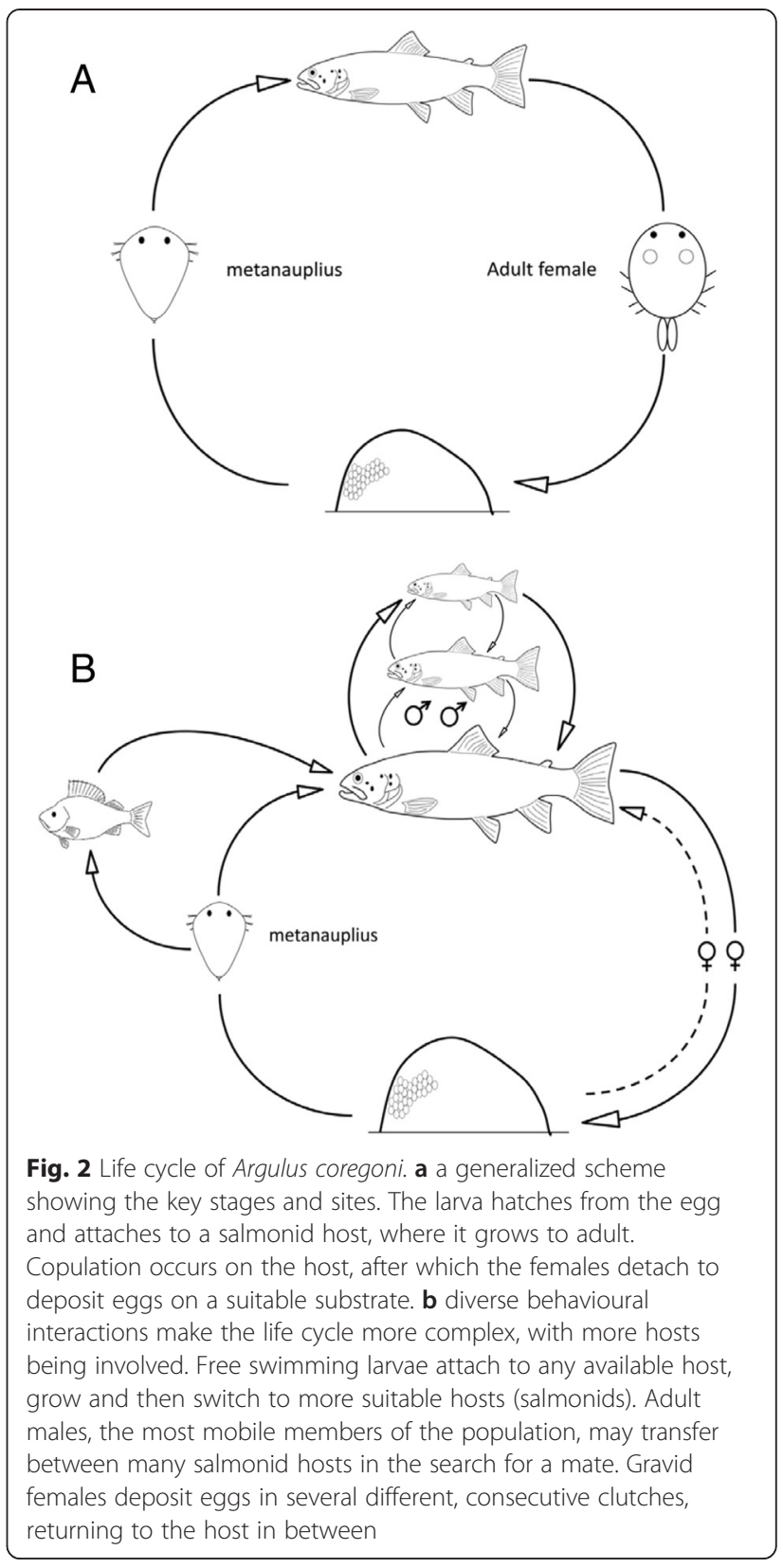

Behavioural relationships between $A$. coregoni and their hosts make life trajectories of these monoxenous parasites rather diverse and variable. An individual $A$. coregoni specimen may change fish hosts many times during its life $[15,22,43]$. Metanauplii and juveniles are strongly attached and rarely abandon their host [22, 42, 43]. With approaching reproduction, the mate searching activity of males increases. They often detach from their host if appropriate mates are not available there. Females detach from their hosts to lay eggs on a suitable substrate. After laying a clutch of eggs, females have to restore their energy levels and, thus, attach to a new host in order to be able to lay the next egg clutch. For $A$. 
coregoni, a specialist on salmonids, there is another reason for changing hosts, i.e. finding an appropriate host. This restricts variations in life trajectories in the larger, oxygen-demanding $A$. coregoni compared with A. foliaceus and, probably, other argulid species, which are all smaller than $A$. coregoni.

\section{Potentials for management and control of fish lice populations}

Ectoparasitic crustaceans can cause epizootics in relation to both marine and freshwater fish farms [9, 50-52], Ectoparasitic infections of fish, including argulosis, result in reduced growth and survival, and also increased production costs in commercial farms [53, 54]. Most of the applied methods to fight against crustacean ectoparasites are based on the use of chemicals [50, 54]. To control crustacean epizootics, and A. coregoni in particular, emamectin benzoate has been widely used in both marine and freshwater aquaculture [55-57]. However, sensitivity to chemical treatments eventually reduces because of habituation. As a result, the Integrated Pest Management concept (IPM) was introduced to aquaculture e.g. $[58,59]$. An IPM programme includes measures to prevent infections and monitor infection levels, which requires a knowledge of the ecology and behaviour of the parasites [24, 47, 60, 61].

Prevention is fundamental to IPM, and a crucial point in preventing the mass development of fish lice is a reduction in egg abundance. A model simulating the population dynamics of $A$. coregoni [62] showed that infection levels largely rely on the number of eggs in the egg-bank [63] and destroying eggs with all available means would greatly reduce the size of a parasite population. To choose an efficient technique for the reduction of egg numbers, the species specific time of intensive spawning and the location and preferred substrate for egg-laying should be taken into account [47, 48,61 . Two groups of measures can be distinguished: 1 ) depriving fish lice of suitable substrates or destroying substrates already covered with laid egg clutches; and 2) attracting gravid females to artificial substrates (egg collectors) $[23,60,64]$. The first approach implies fallowing farm sites between successive stockings [65], draining and drying ectoparasite egg laying sites and surfaces, and/or collecting stones with egg clutches [24]. Within the second approach, artificial egg collectors consisting of dark plates with rough surface are placed in suitable egg laying sites prior to the period of spawning. Most of the eggs are then laid on the underside of the plates [23], which need to be removed and cleaned several times during spawning.

The pool of eggs could also be reduced prior to spawning by shaking $A$. coregoni and A. foliaceus in hand nets in a water container. This simple procedure has proven to be efficient: more than $80 \%$ of the originally attached fish lice were dislodged from the fish. Dislodgement rates of gravid females were especially pronounced. Shaking could be used on a small scale, in response to heavy infections, when other treatment options are limited, or when done in connection with normal fish husbandry practices (fish grading, vaccination, transfer etc.) [24].

To collect free swimming $A$. coregoni for research purposes, 'light traps' have been used [66]. The collection of unattached juveniles with such devices could be efficient, because of their strong reaction to the brightest objects [19]. Certainly, such an approach could not be recommended for the control of the fish lice infections in large farms [50], but it may be used locally as a supplementary method of reducing the number of free-swimming stages.

Attached ectoparasites, including fish lice, cause epithelial damage and evoke stress responses in fish, which may, in turn, induce secondary effects [49]. The most important of these is increased fish susceptibility to various fungal, bacterial and protozoan infections [67-71]. This could be aggravated by reduced nourishment, stunted growth and decreased host immunocompetence $[53,54,72]$. We tested whether infection with A. coregoni leads to a higher susceptibility of fish to a bacterial disease (Flavobacterium columnare) [71]. A clear effect of concomitant infection, exhibited as increased fish mortality, represented the first experimental support for the hypothesis that Argulus spp. can facilitate the transfer of a serious bacterial disease. No effect of concomitant infections with $F$. columnare and cercariae of Diplostomum spathaceum were found [73]. As compared with $D$. spathaceum, skin damage and stress caused by $A$. coregoni are more severe, which makes the latter more likely to result in the introduction of bacterial diseases [71].

The role of Argulus spp. as vectors and their microbiota have not yet been thoroughly studied. Most of the studies on the microbiota of the vectors and their vectorial competence have focused on the terrestrial arthropods e.g., $[35,74,75]$. Our knowledge of the behavioural interactions between fish lice and their hosts suggests that these parasites act as efficient vectors. The ability of Argulus spp. to reduce host resistance (mechanical damage and impaired immunity) and repeated attachment and detachment from the hosts, together with a high level of swimming activity and diverse behaviour, make these parasites potentially more efficient vectors than copepods, a more widely distributed and prolific group of ectoparasitic crustaceans. During their life history, fish lice not only switch hosts many times but also damage them, which may facilitate either the direct (from water) or indirect (via vectors) transfer of pathogens. They also 
cause stress each time when they attach and pierce the skin of a fish [76] and such stress, in turn, reduces immunocompetence [77, 78] and thus may facilitate the transmission of pathogens.

Argulus spp. possess diverse behavioural adaptations that help them in completing their life cycle. When developing measures to counteract epizootics at fish farms, one has to take into account the variety of these adaptations. This may help in the improvement of environmentally friendly measures, which in the long term, could be more efficient than chemical treatments.

\section{Conclusion}

The laying of eggs on the substrate away from the host, and retaining the ability for free swimming throughout their entire life, means that fish lice face the risk of excessive dispersal; this complicates their main and vital tasks, i.e. to find a host and a mate. To counterbalance the risk, Argulus spp. use diverse behaviours resulting in aggregation. This is especially important during the period of reproduction (searching for mates), when males have to find both food and a mate. It is not only the more mobile males but also the females who contribute, in the form of pheromone production, to aggregative mechanisms. Even gravid females benefit from aggregation when they have to return to the host after laying a clutch of eggs. A modified behaviour and physiology of the fish induced by the attached parasites facilitates their finding of, and attachment to, conspecific hosts. We found no evidence for the aggregation of fish lice away from the host. This means that host searching is the pivotal activity in the behavioural repertoire of these parasites. Aggregation occurs on different scales and involves both the aggregation of fish (a host manipulation effect) and the aggregation of parasites on a fish. They can also gather in certain areas of the fish surface. Aggregation is particularly important in cold temperate waters, where the density of both fish and fish lice is usually low. In order to increase the success of host searching, A. foliaceus and A. coregoni are active day and night, employing all of their sensory organs; use alternative behavioural tactics adjusted to temporal variations in fish activity; and modify fish behaviour to make them more available for free swimming parasites. With such diverse and well-developed sensory equipment and behaviour, Argulus spp. can quickly increase their population density in fish farms and cause serious problems when effective control measures are lacking. These problems are related not only to the direct harmful effects of the ectoparasites but also to indirect effects when argulids can act as vectors for pathogens. An increased knowledge of the microbiota is needed to understand whether fish pathogens can replicate within the body of
Argulus spp. and influence their behaviour and physiology, thus enhancing transmission success.

\section{Competing interests}

The authors declare that they have no competing interests.

\section{Authors' contributions}

ETV conceived the review. VM and AP planned the review and drafted the manuscript. All authors read and approved the final manuscript.

\section{Acknowledgements}

We thank Dr. David I. Gibson for valuable comments and for improving English and linguistic form of the manuscript. Konnevesi Research Station provided the facilities and necessary assistance for the experiments. The study was financed by the exchange of scientists between Finland and Russia from the Finnish Academy and by the Russian Foundation for Basic Research (grants 14-04-00090 to V.M. and 13-04-00613 to A.P.).

\section{Author details}

${ }^{1}$ Institute of Ecology and Evolution, Russian Academy of Sciences, 33 Leninskii pr, 119071 Moscow, Russia. Institute of Oceanology, Russian Academy of Sciences, 36 Nakhimovskii pr, 117997 Moscow, Russia.

${ }^{3}$ Department of Biological and Environmental Science, University of Jyväskylä, PL 35, 40351 Jyväskylä, Finland.

Received: 9 April 2015 Accepted: 12 July 2015

Published online: 25 July 2015

\section{References}

1. Maclnnis AJ. How parasites find hosts: Some thoughts on the inception of host-parasite integration. In: Kennedy CR, editor. Ecological Aspects of Parasitology. Amsterdam: North-Holland Publications; 1976. p. 3-20.

2. Combes $\mathrm{C}$, Fournier $\mathrm{A}$, Moné $\mathrm{H}$, Théron A. Behaviours in trematode cercariae that enhance parasite transmission: patterns and processes. Parasitology. 1994;109 Suppl 1:3-13.

3. Haas W. Physiological analyses of host-finding behaviour in trematode cercariae: adaptations for transmission success. Parasitology. 1994;109 Suppl 1:15-29.

4. Poulin R. Evolutionary ecology of parasites. 2nd ed. Princeton, New Jersey: Princeton University Press; 2007.

5. Roberts LS, Janovy Jr J. Foundations of parasitology. 6th ed. Dubuque, lowa: Wm. Brown Publ; 2000.

6. Anderson RM, May RM. Infectious diseases of humans. 6th ed. Oxford: Oxford University Press; 2002.

7. Poly WJ. Global diversity of fishlice (Crustacea: Branchiura: Argulidae) in freshwater. Hydrobiologia. 2008:595:209-12.

8. Møller OS. Branchiura (Crustacea) - Survey of Historical Literature and Taxonomy. Arthropod Syst Phylog. 2009;67:41-55.

9. Costello MJ. How sea lice from salmon farms may cause wild salmonid declines in Europe and North America and be a threat to fishes elsewhere. Proc R Soc B. 2009:276:3385-94

10. Poulin R. "Adaptive" change in the behaviour of parasitized animals: a critical review. Int J Parasitol. 1995;25:1371-83.

11. Moore J. Parasites and the behaviour of animals. Oxford: Oxford University Press; 2002.

12. Thomas F, Adamo S, Moore J. Parasitic manipulation: where are we and where should we go? Behav Process. 2005;68:185-99.

13. Herter K. Reizphysiologische Untersuchungen an der Karpfenlaus Argulus foliaceus (L.). Vergl Physiol. 1927:5:283-370.

14. Kollatsch D. Untersuchungen über die Biologie und Ökologie der Karpfenlaus (Argulus foliaceus L.). Zool Beitr. 1959;5:1-36.

15. Stammer HJ. Beiträge zur Morphologie, Biologie und Bekämpfung der Karpfenläuse. Zeitschr Parsitenk. 1959;19:135-208.

16. Kearn GC. Leeches, lice and lampreys: a natural history of skin and gill parasites of fishes. Dordrecht: Springer; 2004.

17. Mikheev VN, Valtonen ET, Rintamaki-Kinnunen P. Host searching in Argulus foliaceus L. (Crustacea: Branchiura): the role of vision and selectivity. Parasitology. 1998;1 16:425-30.

18. Mikheev VN, Mikheev AV, Pasternak AF, Valtonen ET. Light-mediated host searching strategies in a fish ectoparasite, Argulus foliaceus L. (Crustacea: Branchiura). Parasitology. 2000;120:409-16. 
19. Mikheev VN, Pasternak AF, Valtonen ET. Tuning host specificity during the ontogeny of a fish ectoparasite: behavioural responses to host-induced cues. Par Res. 2004;92:220-4.

20. Mikheev VN, Pasternak AF, Valtonen ET. Host specificity of Argulus coregoni increases at maturation. Parasitology. 2007;134:1767-74.

21. Pasternak AF, Mikheev VN, Valtonen ET. Life history characteristics of Argulus foliaceus L. (Crustacea: Branchiura) populations in Central Finland. Ann Zool Fenn. 2000:37:25-35.

22. Pasternak AF, Mikheev VN, Valtonen ET. Growth and development of Argulus coregoni (Crustacea: Branchiura) on salmonid and cyprinid hosts. Dis Aquat Org. 2004;58:203-7.

23. Hakalahti T, Pasternak AF, Valtonen ET. Seasonal dynamics of egg laying and egg-laying strategy of the ectoparasite Argulus coregoni (Crustacea: Branchiura). Parasitology. 2004;128:655-60.

24. Hakalahti-Siren T, Mikheev VN, Valtonen ET. Control of freshwater fish louse Argulus coregoni: a step towards an integrated management strategy. Dis Aquat Org. 2008;82:67-77.

25. Scaling S-NK. Why is animal size so important? Cambridge: Cambridge University Press; 1984.

26. Madsen N. The anatomy of Argulus foliaceus Linné with notes on Argulus coregoni Thorell and Argulus africanus Thiele. Part I: Integument, central nervous system, sense organs, praeoral spine, and digestive organs. $\mathrm{K}$ Fysiograf Sälsk Handl NF. 1964;74:1-32.

27. Hakalahti T, Bandilla M, Valtonen ET. Delayed transmission of a parasite is compensated by accelerated growth. Parasitology. 2005;131:1-10.

28. Poulin R, FitzGerald GJ. A possible explanation for the aggregated distribution of Argulus canadensis Willson, 1916 (Crustacea: Branchiura) on juvenile sticklebacks (Gasterostaeidae). J Parasitol. 1989;75:58-60.

29. Mikheev VN, Pasternak AF. Parasitic crustaceans influence social relations in fish. Dokl Biol Sci. 2010;432:1-3.

30. Poulin R, Curtis MA, Rau ME. Responses of the fish ectoparasite Salmincola edwardsii (Copepoda) to stimulation, and their implication for host finding. Parasitology. 1990;100:417-21.

31. Poulin R, Rau ME, Curtis MA. Infection of brook trout fry, Salvelinus fontinalis, by ectoparasitic copepods: the role of host behaviour and initial parasite load. Anim Behav. 1991:41:467-76.

32. Pitcher TJ, Parrish JK. Functions of shoaling behaviour in teleosts. In: Pitche TJ, editor. Behaviour of Teleost Fishes. 2nd ed. London: Chapman and Hall; 1993. p. 363-438.

33. Krause J, Ruxton GD. Living in Groups. Oxford: Oxford University Press; 2002.

34. Bader JA, Nusbaum KE, Shoemaker CA. Comparative challenge model of Flavobacterium columnare using abraded and unabraded channel catfish, Ictalurus punctatus (Rafinesque). J Fish Dis. 2003;26:461-7.

35. Minard G, Mavingui $P$, Moro CV. Diversity and function of bacterial microbiota in the mosquito holobiont. Parasit Vectors. 2013;6:146.

36. Verhulst NO, Andriessen R, Groenhagen U, Bukovinszkine Kiss G, Schulz S, Takken W, et al. Differential attraction of malaria mosquitoes to volatile blends produced by human skin bacteria. PLOS ONE. 2010:5(12):e15829.

37. Lambrechts L, Scott TW. Mode of transmission and the evolution of arbovirus virulence in mosquito vectors. Proc Biol Sci. 2009:276:1369-78.

38. Douglas AE. Lessons from studying insect symbioses. Cell Host Microbe. 2011:10:359-67.

39. Valtonen ET, Holmes JC, Koskivaara M. Eutrophication, pollution and fragmentation: effects on parasite communities in roach (Rutilus rutilus) and perch (Perca fluviatilis) in four lakes in Central Finland. Can J Fish Aquat Sci. 1997:54:572-85.

40. Shimura S. Seasonal occurrence, sex ratio and site preference of Argulus coregoni Thorell (Crustacea: Branchiura) parasitic on cultured freshwater salmonids in Japan. Parasitology. 1983;86:537-52.

41. Hakalahti T, Valtonen ET. Population structure and recruitment of the ectoparasite Argulus coregoni Thorell (Crustacea: Branchiura) on a fish farm. Parasitology. 2003;127:79-85.

42. Pasternak AF, Mikheev VN, Valtonen ET. Adaptive significance of the sexual dimorphism in a fish ectoparasite Argulus coregoni (Crustacea: Branchiura). Dokl Biol Sci. 2004:398:1-4.

43. Bandilla M, Hakalahti-Siren T, Valtonen ET. Patterns of host switching in the fish ectoparasite Argulus coregoni. Behav Ecol Sociobiol. 2008;62:975-82.

44. Bandilla M, Hakalahti-Sirén T, Valtonen ET. Experimental evidence for a hierarchy of mate- and host-induced cues in a fish ectoparasite, Argulus coregoni (Crustacea: Branchiura). Int J Parasitol. 2007;37:1343-9.
45. Mordue AJ, Birkett MA. A review of host finding behaviour in the parasitic sea louse, Lepeophtheirus salmonis (Caligidae: Copepoda). J Fish Dis. 2009;32:3-13.

46. Kabata Z. Copepoda (Crustacea) parasitic on fishes: problems and perspectives. In: Lumsden WHR, Muller R, Baker JR, editors. Advances in Parasitology. London: Academic; 1981. p. 1-71.

47. Taylor NGH, Wootten $\mathrm{R}$, Sommerville $\mathrm{C}$. The influence of risk factors on the abundance, egg laying habits and impact of Argulus foliaceus in stillwater trout fisheries. J Fish Dis. 2009;32:509-19.

48. Mikheev VN, Pasternak AF, Valtonen ET, Lankinen Y. Spatial distribution and hatching of overwintered eggs of a fish ectoparasite, Argulus coregoni (Crustacea: Branchiura). Dis Aquat Org. 2001;46:123-8.

49. Walker PD, Flik G, Wendelaar Bonga SE. The biology of parasites from the genus Argulus and a review of the interactions with its host. In: Wiegetjes GF, Flik G, editors. Host-parasite interactions. Oxford: Garland Science/BIOS Scientific Publishers; 2004. p. 107-29.

50. Costello MJ. Review of methods to control sea lice (Caligidae: Crustacea) infestations on salmon farms. In: Boxshall GA, Defaye D, editors. Pathogens of wild and farmed fish: sea lice. Chichester: Ellis Horwood; 1993. p. 219-52.

51. Krkošek M, Lewis MA, Morton A, Frazer LN, Volpe JP. 2006. Epizootics of wild fish induced by farmed fish. Proc Natl Acad Sci U S A. 2006;103:15506-10.

52. Pekmezci GZ, Yardimci B, Bolukbas CS, Beyhan YE, Umur S. Mortality due to heavy infestation of Argulus foliaceus (Linnaeus, 1758) (Branchiura) in pond-reared carp, Cyprinus carpio L., 1758 (Pisces). Crustaceana. 2011:84:553-7.

53. Menezes J, Ramos MA, Pereira TG. Moreira de Silva A. Rainbow trout culture failure in a small lake as a result of massive parasitosis related to careless fish introductions. Aquaculture. 1990;89:123-6.

54. Costello MJ. Ecology of sea lice parasitic on farmed and wild fish. Trends Parasitol. 2006:22:475-83.

55. Stone J, Sutherland $\mathrm{IH}$, Sommerville $\mathrm{C}$, Richards RH, Varma KJ. Field trials to evaluate the efficacy of emamectin benzoate as an oral treatment of sea lice, Lepeopthreirus salmonis (Krøyer) and Caligus elongatus (Nordman), infestations in Atlantic salmon. Salmo salar Aquaculture. 2000:186:205-19.

56. Duston J, Cusack RR. Emamectin benzoate: an effective in-feed treatment against the gill parasite Salmincola edwardsii on brook trout. Aquaculture. 2002;207:1-9.

57. Hakalahti T, Lankinen Y, Valtonen ET. Efficacy of emamectin benzoate in the control of Argulus coregoni (Crustacea: Branchiura) on rainbow trout. Dis Aquat Org. 2004;60:197-204.

58. Sommerville C. Integrated control - an example: sea lice of Atlantic salmon. Parasitol Int. 1998;47:85

59. AJ M (L), Pike AW. Integrated pest management in salmon farming. Pest Manag Sci. 2002;58:513-629.

60. Gault NFS, Kilpatric DJ, Steward MT. Biological control of the fish louse in a rainbow trout fishery. J Fish Biol. 2002;60:226-37.

61. Taylor NGH, Wootten R, Sommerville C. Using length-frequency data to elucidate the population dynamics of Argulus foliaceus (Crustacea: Branchiura). Parasitology. 2009:136:1023-32.

62. Fenton A, Hakalahti T, Bandilla M, Valtonen ET. The impact of variable hatching rates on parasite control: a model of Argulus coregoni in a Finnish fish farm. J Appl Ecol. 2006;43:660-8.

63. Hakalahti T, Hakkinen H, Valtonen ET. Ectoparasitic Argulus coregoni hedge their bets - studies on egg hatching dynamics. Oikos. 2004;107:295-302.

64. Bauer ON. Parasites of freshwater fish and the biological basis for their control. Bull State Sci Res Inst Lake River Fish. 1962;49:3-215. (in Russian) available in translation: Israel Program for Scientific Translations, Silvan Press, Jerusalem.

65. Bron JE, Sommerville C, Wootten R, Rae GH. Fallowing of marine Atlantic salmon, Salmo salar L., farms as a method for the control of sea lice, Lepeophtheirus salmonis (Krøyer, 1837). J Fish Dis. 1993;16:487-93.

66. Aagaard K. En ny metode for å fange stor fiskelus, Argulus coregoni, og litt om dens biologi. Fauna (Oslo). 1978;31:23-8

67. Cusack R, Cone DK. A review of parasites as vectors of viral and bacterial diseases of fish. J Fish Dis. 1986;9:169-71.

68. Bakke TA, Harris PD. Diseases and parasites in wild Atlantic salmon (Salmo salar) populations. Can J Fish Aquat Sci. 1998;55:247-66.

69. Mustafa A, Speare DJ, Daley J, Conboy GA, Burka J.J. Enhanced susceptibility of seawater cultured rainbow trout, Oncorhynchus mykiss (Walbaum), to the microsporidian Loma salmonae during a primary infection with a sea louse, Lepeophtheirus salmonis. J Fish Biol. 2000;23:337-41. 
70. Tully O, Nolan DT. A review of the population biology and hostparasite interactions of the sea louse Lepeophtheirus salmonis (Copepoda: Caligidae). Parasitology. 2002;124:165-82.

71. Bandilla M, Valtonen ET, Suomalainen L-R, Aphalo PJ, Hakalahti T. A link between ectoparasite infection and susceptibility to bacterial disease in rainbow trout. Int J Parasitol. 2006;36:987-91.

72. Bowers JM, Mustafa A, Speare DJ, Conboy GA, Brimacombe M, Sims DE, et al. The physiological response of Atlantic salmon, Salmo salar L., to a single experimental challenge with sea lice, Lepeophtheirus salmonis. J Fish Dis. 2000;23:165-72.

73. Suomalainen L-R, Tiirola MA, Valtonen ET. Influence of rearing conditions on Flavobacterium columnare infection of rainbow trout, Oncorhynchus mykiss (Walbaum). J Fish Dis. 2005:28:271-7.

74. Kluiters G, Swales H, Baylis M. Local dispersal of palaearctic Culicoides biting midges estimated by mark-release-recapture. Parasit Vectors. 2015;8:86

75. Yu Z, Wang H, Wang T, Sun W, Yang X, Liu J. Tick-borne pathogens and the vector potential of ticks in China. Parasit Vectors. 2015;8:24.

76. Laitinen M, Siddall R, Valtonen ET. Bioelectronic monitoring of parasite induced stress in brown trout and roach. J Fish Biol. 1996;48:228-41.

77. Salonius K, Iwama GK. Effects of early rearing environment on stress response, immune function, and disease resistance in juvenile coho (Oncorhynchus kisutsch) and chinook salmon (O. tshawytscha). Can J Fish Aquat Sci. 1993;50:759-66.

78. Engelsma M, Hougee S, Nap D, Hofenk M, Rombout JHWM, van Muiswinkel WB, et al. Multiple acute temperature stress affects leucocyte populations and antibody responses in common carp, Cyprinus carpio L. Fish Shellfish Immunol. 2003;15:397-410.

\section{Submit your next manuscript to BioMed Central and take full advantage of:}

- Convenient online submission

- Thorough peer review

- No space constraints or color figure charges

- Immediate publication on acceptance

- Inclusion in PubMed, CAS, Scopus and Google Scholar

- Research which is freely available for redistribution 